\title{
Smell and taste alterations in COVID-19 patients: a systematic review
}

\author{
Laura Faustino Gonçalves ${ }^{\mathbf{1}}$ \\ (iD) Ana Inês Gonzáles ${ }^{2}$ \\ iD Karina Mary Paiva 3 \\ Fernanda Soares Aurélio Patatt ${ }^{4}$ \\ (iD) Janaina Viana Stolz ${ }^{5}$ \\ (iD) Patrícia Haas 6
}

\begin{abstract}
1.Graduanda em Fonoaudiologia pela Universidade Federal de Santa Catarina - UFSC, Florianópolis, SC, Brasil 2. Universidade do Estado de Santa Catarina, Centro de Ciências da Saúde e do Esporte CEFID-UDESC, Núcleo de Cardiologia e Medicina do Exercício, Florianópolis, SC, Brasil 3. Professora Doutora do Curso de Fonoaudiologia pela Universidade Federal de Santa Catarina - UFSC, Florianópolis, SC, Brasil 4. Doutora pela Universidade de Brasília (UnB), Brasília, DF, Brasil 5. Médica Janaina Viana Stolz Formada pela Universidade Federal de Pelotas, Pelotas, RS, Brasil 6. Professora Doutora do Curso de Fonoaudiologia pela Universidade Federal de Santa Catarina - UFSC, Florianópolis, SC, Brasil
\end{abstract}

http://dx.doi.org/10.1590/1806-9282.66.11.1602

\section{SUMMARY}

OBJECTIVE: To present scientific evidence based on a systematic review of the literature (PRISMA) to systematize information on smell and taste alterations in patients diagnosed with COVID-19.

METHODS: The studies were selected through combinations based on the Medical Subject Headings (MeSH). The MEDLINE (PubMed), LILACS, SciELO, and BIREME databases were used. The search encompassed articles published from January 2010 to May 2020, with no restriction of language or localization.

RESULTS: A total of 665 retrieved articles had the potential for inclusion. Of these, two answered the research question, which was to verify the smell and taste alterations in patients diagnosed with COVID-19.

CONCLUSION: The results found in this review demonstrated that there likely is an association between self-reported smell and taste dysfunctions and COVID-19 infection in such patients.

KEYWORDS: Anosmia; Coronavirus infections; Smell dysfunctions; Ageusia.

\section{INTRODUCTION}

The disease caused by the new coronavirus (COVID-19) has brought about a worldwide viral pandemic, which emerged in East Asia and quickly spread to the other continents. This infection, caused by the type-2 coronavirus, is responsible for triggering severe acute respiratory syndrome (SARS-CoV-2), and symptoms such as fever, cough, fatigue, and myalgia are usually reported'.
COVID-19 was characterized by the World Health Organization (2020) as a global pandemic and health emergency on March 11, 2020, which led to a worldwide concern ${ }^{2}$. The disease has already led to the death of more than 300,000 people, while there are more than 5 million confirmed cases worldwide ${ }^{3}$.

As COVID-19 infections spread throughout Europe, an atypical new manifestation of the disease was 
evidenced, with a high prevalence of individuals with reported symptoms of olfactory and gustatory alterations. Initially, neither anosmia nor ageusia was considered symptoms of COVID- $19^{4}$, although these alterations typically occur in viral infections in the field of otorhinolaryngology. Currently, smell and taste alteration symptoms have been constantly reported by COVID-19 patients, indicating that the oral and nasal tissues may contain virus-host cells ${ }^{5}$.

Olfactory dysfunction (OD) may appear after infections occur in the upper respiratory tract - called postviral anosmia. However, the precise underlying pathogenesis has not been fully identified when present in COVID-19 cases ${ }^{6}$. Many viruses can lead to OD and ageusia through an inflammatory reaction in the nasal mucosa and the development of rhinorrhea. When associated with COVID-19 infections, though, these alterations seem to have peculiar characteristics, as they are not related to rhinorrhea ${ }^{7}$. The description of these otorhinolaryngological symptoms in association with COVID-19 is still scarce.

Ageusia is the loss of the functions of taste, frequently mistaken for anosmia, since the tongue can only indicate texture and distinguish the tastes perceived through smell ${ }^{7}$. It is observed that ageusia can be another one of the COVID-19 symptoms. Hence, its inclusion in data collection will help provide better information about the SARS-CoV-2 infection ${ }^{8}$.

$\mathrm{Mao}^{9}$, when analyzing the neurological manifestation frequency in 214 patients infected with COVID-19, found anosmia in 5.1\% and ageusia in 5.6\% of them. In Europe, studies have reported a significant detection of chemosensitive disorders in COVID-19 patients, ranging from $19.4 \%$ to $88 \%^{10,11}$.

Given the present scenario, this systematic review aimed to verify the already available scientific evidence on smell and taste alterations of patients diagnosed with COVID-19, seeking to answer the following research question: What olfactory and gustatory alterations occur in patients diagnosed with COVID-19?

\section{METHODS}

\section{Research design and search strategies}

The systematic review followed the recommendations of the Preferred Reporting Items for Systematic Reviews and Meta-Analyses (PRISMA) ${ }^{12}$. The scientific articles were searched by two independent researchers in the MEDLINE (PubMed) (https://www.ncbi. nlm.nih.gov/pubmed/), LILACS (http://lilacs.bvsalud. org/), SciELO (http://www. scielo.br/), and BIREME (https://bvsalud.org/) databases, with no restrictions of language or location; the search was carried on until May 2020. As a complement, a manual search was conducted on the references of the articles already included in the research; also, grey literature was searched in Google Scholar. The research was structured and organized according to the PICOS framework - an acronym that stands for Population, Intervention, Control, Outcomes, and Study (Table 1).

\section{TABLE 1. DESCRIPTION OF THE PICOS COMPONENTS}

\begin{tabular}{l|l} 
Acronym & Definition \\
\hline$P$ & Patients \\
\hline I & Coronavirus \\
\hline C & Loss of smell and taste \\
\hline S & Infection \\
\hline & $\begin{array}{l}\text { Descriptive study } \\
\text { Cross-sectional study } \\
\text { Observational study }\end{array}$ \\
\hline
\end{tabular}

Source: Developed by the authors.

The descriptors were selected based on the Health Sciences Descriptors (DeCS) and Medical Subject Headings (MeSH). The descriptors and Boolean operators used in the searches were: (COVID) or (taste) or (smell).

\section{SELECTION CRITERIA}

\section{Inclusion criteria}

We selected studies whose design was descriptive, cross-sectional, cohort, clinical, randomized, and case study. The search for articles had no restriction of language or location, encompassing studies published from January 2010 to May 2020. The inclusion and exclusion criteria developed in this research are presented in Table 2.

\section{Exclusion criteria}

Studies designed as letters to the editor, guidelines, literature reviews, systematic reviews, meta-analyses, and abstracts were excluded. Besides these, animal research and undescribed or unclear studies were also excluded. The exclusion criteria are shown in Table 2 , as well.

\section{Data analysis}

The data for the eligibility process of the studies were extracted using a spreadsheet developed in 
TABLE 2. SUMMARY OF THE INCLUSION AND EXCLUSION CRITERIA

\begin{tabular}{|c|c|}
\hline \multicolumn{2}{|l|}{ Inclusion criteria } \\
\hline Design & $\begin{array}{l}\text { Case reports } \\
\text { Case-control studies } \\
\text { Controlled clinical trials } \\
\text { Cohort studies } \\
\text { Screening studies } \\
\text { Observational studies }\end{array}$ \\
\hline Localization & No restriction \\
\hline Language & No restriction \\
\hline \multicolumn{2}{|l|}{ Exclusion criteria } \\
\hline Design & $\begin{array}{l}\text { Letters to the editor } \\
\text { Guidelines } \\
\text { Literature reviews } \\
\text { Systematic reviews } \\
\text { Meta-analyses }\end{array}$ \\
\hline Studies & $\begin{array}{l}\text { Conducted with animals } \\
\text { Unclear studies } \\
\text { Inadequate or poorly described }\end{array}$ \\
\hline Form of publication & Only abstract \\
\hline
\end{tabular}

Excel by the researchers for systematic reviews. The extracted data were entered in the spreadsheet, initially by one of the researchers, and then conferred by another one. When necessary, a third researcher was consulted regarding the inclusion of articles. The data obtained from the eligible studies were also entered in a spreadsheet using the same software.

\section{RESULTS}

Initially, 665 articles were selected, which were reduced to 640 after the repeated ones were excluded. Then, the titles and abstracts were analyzed, leading to the exclusion of 505 papers that did not meet the inclusion criteria; 135 articles were left. Afterward, 130 of these were excluded after having their abstracts

FIGURE 1. FLOWCHART OF THE SEARCH AND ANALYSIS OF THE ARTICLES

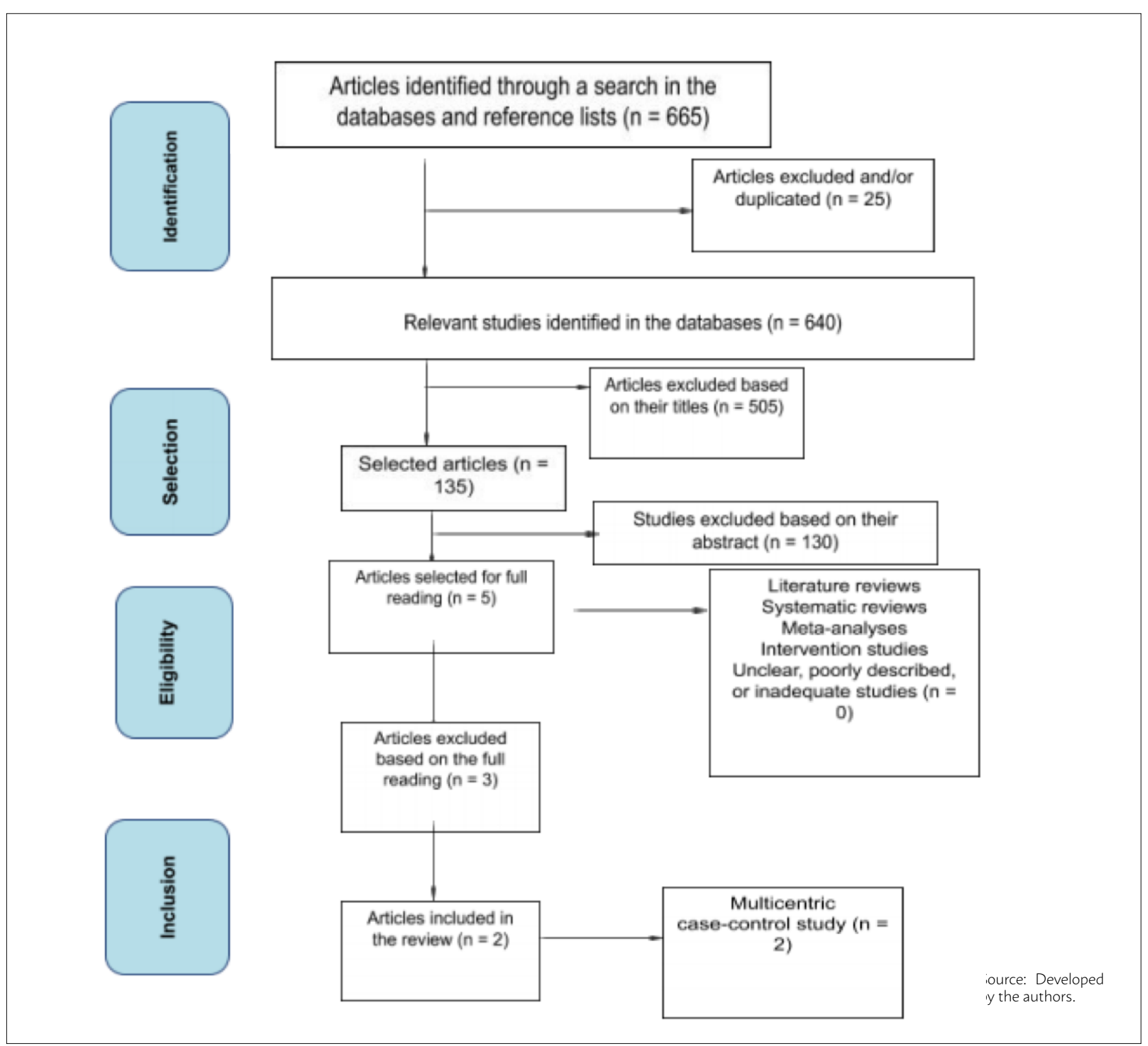


read, and the remaining five were fully read. Finally, two articles were included in the research, as they answered the research question, making them eligible according to the PRISMA criteria used to develop this research $^{13}$ (Figure 1).

Both studies included in this systematic review were multicentric case-control studies ${ }^{14,15}$, comprising a combined sample of 464 individuals.

The research by Beltrán-Corbellini ${ }^{14}$ was developed in Spain. They administered a questionnaire regarding alterations in smell and/or taste in patients infected with COVID-19 and patients infected with the influenza virus. The questionnaires were administered during hospitalization routine clinical assessments, from March 23 to 25, 2020.

The group of patients diagnosed with COVID-19 comprised people over 18 years old who tested positive for this infection between 2019 and 2020. This study did not include specific chemosensory tests. A total of 79 patients with COVID-19 were included in the case group. The control group, in turn, comprised 46 patients with influenza virus infections (41 with A-H1; one with A-H3, four with subtype B) ${ }^{14}$.

As for the distribution of the individuals in the groups regarding gender, the number of men in the COVID-19 group was 48 (60.8\%), and in the influenza group, 19 (47.5\%). The mean age in the COVID-19 group was 61.6 years, and 61.1 in the influenza group. Recent-onset smell and/or taste alterations were significantly more present in the case group $(n=31 ; 39.2 \%)$ than in the control group $(n=5 ; 12.5 \% ; p=0.003)^{14}$.

As a result of the research, the authors identified that the patients with COVID-19 with recently acquired symptoms were significantly younger than the COVID19 patients without these alterations. Of the recently acquired smell and/or taste dysfunctions reported in the case group, 25 (80.6\%) had smell alterations and 28 (90.3\%) taste alterations. Twenty-two patients (70.9\%) had an acute onset of these dysfunctions, while in 11 (35.5\%) the alterations were initial manifestations of COVID-19. Four patients (12.9\%) reported concomitant nasal obstruction, and 21 patients $(67.7 \%)$ were capable of distinguishing sweet and bitter, despite the dysfunctions. The smell and/or taste alterations lasted for seven days on average. In the control group, all those who had recently developed smell and/or taste alterations reported full recovery by the time they were discharged from the hospital ${ }^{14}$.

The second study ${ }^{15}$ included in this research was carried out in four Italian hospitals. The olfactory and gustatory functions were objectively assessed in two groups of patients: quarantined health professionals $(n=161)$, with a positive nasopharyngeal swab for SARS-CoV-2 infection; and hospitalized patients $(\mathrm{n}=$ 184 ) with a positive nasopharyngeal swab for SARS$\mathrm{CoV}-2$ infection. The participants' mean age was 50 years. After confirming the positive result in the first nasopharyngeal swab, variables such as gender, age, comorbidities that might be a reason for exclusion, presence and onset of symptoms of the disease were preliminarily collected.

Following the criteria proposed by Tian ${ }^{16}$, the individuals in the research ${ }^{15}$ were divided into four groups according to clinical severity, namely: asymptomatic, mild (mild symptoms without radiological evidence of pneumonia), moderate (radiological evidence of pneumonia without dyspnea or respiratory insufficiency), and severe (radiological evidence of pneumonia with dyspnea and respiratory insufficiency). Regarding functional assessment in the group comprising quarantined health professionals, after testing positive for COVID-19 through the nasopharyngeal swab, the smell discrimination capacity was tested through seven groups of smells. For each one of them, the patient gave a score from 0 (no distinction) to 10 (normal distinction). The gustatory function was assessed regarding each of the primary tastes (sweet, salty, sour, and bitter) through solutions prepared by the patient, as proposed by Massarelli ${ }^{17}$.

For the group of hospitalized patients, both the olfactory threshold and the smell distinction ability were assessed. The olfactory function was assessed through the Connecticut olfactory test (CCCRC), a validated and widely used simple orthonasal olfaction test. It includes an assessment of the butanol threshold and a smell identification of 10 items, using common smells ${ }^{18,19}$. The same standardized and validated test - which investigates the capacity to perceive the four primary tastes - used with the professionals' group was also used to assess this group's gustatory function.

The study ${ }^{15}$ included patients in all stages of clinical severity of the disease: 10 (2.9\%) were asymptomatic; $168(48.7 \%)$ had a mild presentation of the disease; 140 (40.6\%) moderate; 27 (7.8\%) severe. The chemosensitive dysfunctions during COVID-19 were self-reported by 256 patients ( $74.2 \%$ of the study's population); $79.3 \%$ of these patients reported combined chemosensitive dysfunctions; $8.6 \%$ olfactory dysfunctions alone; $12.1 \%$ taste alterations alone. At the time of the test, 
full remission of the alteration was self-reported by $31.3 \%$ of the patients regarding smell, and by $50.4 \%$ regarding taste. The objective results obtained from the olfactory and gustatory assessments of both study groups were analyzed together.

No significant correlation was found between the gustatory and olfactory scores and the patients' gender or age. A more detailed analysis showed that there is a significant improvement in the scores between the first and second weeks of the disease, though not between the second and the third ones. No significant correlation was found between the severity of COVID19 and the presence or extension of chemosensitive dysfunctions. On the other hand, the duration of chemosensitive symptoms for more than seven days showed a statistically significant correlation with the

TABLE 3. SUMMARY OF THE RESULTS FOUND IN THE ARTICLES INCLUDED IN THE REVIEW.

\begin{tabular}{|c|c|c|c|c|c|}
\hline $\begin{array}{l}\text { Author/Year/ } \\
\text { Localization/Type } \\
\text { of study }\end{array}$ & Purpose & Sample & Procedures & Results & Conclusion \\
\hline $\begin{array}{l}\text { Beltran-Corbellini, } \\
\text { et al. } \\
(2020) \\
\text { Spain } \\
\text { Multicentric } \\
\text { case-control study }\end{array}$ & $\begin{array}{l}\text { To determine } \\
\text { whether the } \\
\text { recent-onset smell } \\
\text { and/or taste dys- } \\
\text { functions are more } \\
\text { frequent among } \\
\text { COVID-19 patients } \\
\text { than in influenza } \\
\text { patients }\end{array}$ & $\begin{array}{l}\text { Case group } \\
\text { ( } 79) \text { : patients } \\
\text { diagnosed with } \\
\text { COVID-19-48 } \\
\text { men and } 31 \\
\text { women, mean age } \\
61.6 \text { years } \\
\text { Control group } \\
\text { (40): influenza } \\
\text { patients ( } 41 \text { with } \\
\text { A-H1; } 1 \text { with } \\
\text { A-H3; four with } \\
\text { subtypes B) - } \\
19 \text { men and } 21 \\
\text { women, mean age } \\
61.6 \text { years }\end{array}$ & $\begin{array}{l}\text { Questionnaire on smell } \\
\text { and/or taste alterations, } \\
\text { administered between } \\
\text { March } 23 \text { and } 25,2020, \\
\text { during hospitalization } \\
\text { routine clinical assess- } \\
\text { ments. No specific } \\
\text { chemosensory tests were } \\
\text { used. }\end{array}$ & $\begin{array}{l}\text { Among the patients } \\
\text { with COVID-19 with } \\
\text { smell and/or taste } \\
\text { dysfunctions with } \\
\text { recent onset, } 80.6 \% \\
\text { presented alterations } \\
\text { in smell, and } 90.3 \% \text {, } \\
\text { alterations in taste; } \\
70.9 \% \text { had an acute } \\
\text { onset of smell and/or } \\
\text { taste dysfunctions. In } \\
35.5 \%, \text { the smell and/or } \\
\text { taste dysfunctions were } \\
\text { the initial COVID-19 } \\
\text { manifestation. 12.9\% } \\
\text { reported concomitant } \\
\text { nasal obstruction, and } \\
67.7 \% \text { were capable of } \\
\text { distinguishing sweet } \\
\text { and bitter, despite their } \\
\text { smell and/or taste } \\
\text { dysfunctions. Among } \\
\text { the influenza patients, } \\
\text { all those who had any } \\
\text { recent-onset smell and/ } \\
\text { or taste dysfunctions } \\
\text { reported full recovery. }\end{array}$ & $\begin{array}{l}\text { The recent-onset } \\
\text { smell and/or taste } \\
\text { alterations were } \\
\text { significantly more } \\
\text { frequent among } \\
\text { COVID-19 patients } \\
\text { than among influ- } \\
\text { enza patients. They } \\
\text { usually had an acute } \\
\text { onset and were an } \\
\text { initial manifesta- } \\
\text { tion. It is suggested } \\
\text { that the smell and/ } \\
\text { or taste alterations } \\
\text { be assessed in the } \\
\text { anamnesis as an in- } \\
\text { dicator for COVID-19 } \\
\text { to support their } \\
\text { self-isolation in the } \\
\text { present epidemic } \\
\text { context. }\end{array}$ \\
\hline $\begin{array}{l}\text { Vaira et al., } \\
2020 \\
\text { Italy } \\
\text { Multicentric } \\
\text { case-control study }\end{array}$ & $\begin{array}{l}\text { To investigate the } \\
\text { smell and/or taste } \\
\text { dysfunctions in } \\
\text { COVID-19 patients. }\end{array}$ & $\begin{array}{l}\text { Quarantined } \\
\text { health profes- } \\
\text { sionals (161). } \\
\text { Hospitalized } \\
\text { patients (184). } \\
\text { The participants' } \\
\text { mean age was } 50 \\
\text { years. }\end{array}$ & $\begin{array}{l}\text { All the participants in the } \\
\text { study had to present a } \\
\text { positive nasopharyngeal } \\
\text { swab for SARS-CoV-2 } \\
\text { infection. } \\
\text { The gustatory function } \\
\text { was assessed regarding } \\
\text { each of the primary } \\
\text { tastes through solutions } \\
\text { prepared by the patient. } \\
\text { In the group of quaran- } \\
\text { tined professionals, the } \\
\text { olfactory discrimination } \\
\text { capacity was tested } \\
\text { through seven smell } \\
\text { groups; for each of them, } \\
\text { the patient gave a score } \\
\text { from O (no distinction) to } \\
10 \text { (normal distinction). } \\
\text { In the group of hospital- } \\
\text { ized patients, the olfacto- } \\
\text { ry function was assessed } \\
\text { through the orthonasal } \\
\text { Connecticut olfactory } \\
\text { test (CCCRC). }\end{array}$ & $\begin{array}{l}\text { Chemosensitive disor- } \\
\text { ders were self-reported } \\
\text { by } 256 \text { patients ( } 74.2 \%) \text {. } \\
\text { Of these, } 79.3 \% \text { report- } \\
\text { ed combined disorders; } \\
8.6 \% \text {, olfactory alone; } \\
12.1 \% \text { taste alterations } \\
\text { alone. No significant } \\
\text { correlations were found } \\
\text { between the presence } \\
\text { and severity of chemo- } \\
\text { sensitive dysfunctions } \\
\text { and the severity of the } \\
\text { clinical condition. On } \\
\text { the other hand, there is } \\
\text { a significant correlation } \\
\text { between the duration of } \\
\text { the olfactory and gusta- } \\
\text { tory symptoms and the } \\
\text { severe progression of } \\
\text { coviD-19 }\end{array}$ & $\begin{array}{l}\text { The presence } \\
\text { of olfactory and } \\
\text { gustatory alterations } \\
\text { may indicate a } \\
\text { milder course, but it } \\
\text { suggests that those } \\
\text { with a more severe } \\
\text { presentation of the } \\
\text { disease neglect these } \\
\text { symptoms in the } \\
\text { condition of severe } \\
\text { respiratory disease. } \\
\text { This study provides } \\
\text { more evidence of a } \\
\text { high prevalence of } \\
\text { self-reported smell } \\
\text { and taste dysfunc- } \\
\text { tions in association } \\
\text { with COVID-19 } \\
\text { infection. }\end{array}$ \\
\hline
\end{tabular}


moderate and severe progression of COVID-19 ${ }^{15}$. The main characteristics described in the studies included for analysis are seen in Table 3.

\section{DISCUSSION}

Regarding the evaluation of the methodological quality of the studies eligible for this review, both obtained a score of 12 in the modified protocol by Pithon $^{13}$, demonstrating their high quality.

Alterations in smell and/or taste have been recently pointed out as high-prevalence symptoms in patients diagnosed with COVID-19. The lack of objective data to quantify the extension of the problem suggests that in many countries these symptoms have not yet been included in the COVID-19 guidelines. This research aimed to verify the possible relationship between olfactory and/or gustatory alterations and the infection with the new coronavirus in patients thus diagnosed.

One of the publications comprising this study ${ }^{15}$ reports that chemosensitive dysfunctions during COVID-19 were self-reported by $74.2 \%$ of the study's population. Data from both studies analyzed corroborate other research that correlates olfactory and taste alterations in COVID-19 patients ${ }^{18}$. The prevalence of chemosensitive dysfunctions in association with COVID-19 has been reported in the literature between $19.4 \%$ and $85.6 \%^{19,20,10,21}$.

Lechien $^{20}$ reported a series of 417 patients diagnosed with COVID-19 - 85.6\% and 88.0\% reported olfactory and gustatory dysfunction, respectively. Olfactory dysfunction appeared before other symptoms in $11.8 \%$ of the cases. Kaye ${ }^{22}$ verified that of the 237 patients with COVID-19, 73\% reported anosmia even before being diagnosed with the disease, and the loss of smell was the initial symptom in $26.6 \%$.

Gustatory and olfactory dysfunctions seem to be important symptoms, standing out as clues for the diagnosis of COVID-19, particularly in the initial stage of the disease, which requires it to be acknowledged as a symptom of COVID-19 infection ${ }^{4}$. Inflammation of the nasal cavity can impair the sense of smell; it is also possible that the virus infects and damages the nasal epithelial cells ${ }^{23}$. The evidence shows that OD is highly prevalent in COVID-19, up to $80 \%$ of the patients reported subjective OD, and objective olfactive tests revealed an even higher prevalence. OD is frequently accompanied by taste dysfunction. Up to $25 \%$ of the patients with COVID-19 may present sudden onset OD as the first symptom ${ }^{24}$.
As for duration, in the study by Beltrán-Corbel$\operatorname{lini}^{24}$, the symptoms lasted seven days. Another study ${ }^{15}$ ] revealed an improvement between the first and second weeks of the disease. Other studies s4,25,26,27 $^{24}$ indicate that the clinical onset of chemosensitive alterations takes place mainly in the initial stages of COVID-19 infection, usually in the first three days. However, the study by Hopkins ${ }^{28}$ verified that $80 \%$ of the patients reported recovery from the loss of smell some weeks after its onset, reaching a plateau after three weeks.

Nevertheless, Vaira ${ }^{15}$ reported that in patients with COVID-19, the smell and/or taste alterations are not accompanied by nasal obstruction or other rhinitis symptoms. This is probably due to the direct damage caused by the virus on the olfactory and gustatory receptors. It is not possible to determine yet whether there will be full recovery of the olfactory and gustatory functions, or how long it will take. The existence of different gustatory and olfactory recovery patterns can be explained by selective neurological impairments. The loss of taste is not a retronasal olfaction dysfunction in some patients. Further experimental studies are necessary to better understand the physiopathological mechanisms underlying the development of olfactory and gustatory dysfunctions ${ }^{29}$.

In one of the studies ${ }^{14}$, the authors used no specific chemosensory tests. In contrast, another study selected for this research ${ }^{14}$ performed the nasopharyngeal swab test, olfactory discrimination capacity test, gustatory function test ${ }^{17}$, and the Connecticut olfactory test (CCCRC) $)^{18,30}$. The incompatibility between self-reported chemosensory alterations and psychophysical tests has already been suggested in a recent study ${ }^{31}$. Hence, the prevalence of these alterations related to COVID-19 would be overestimated in the epidemiological studies, in which the loss of smell was based on subjective reports.

\section{CONCLUSIONS}

Although medical entities and researchers have increasingly turned their attention to the association between COVID-19 infection and possible smell and taste alterations, more detailed descriptions are necessary regarding the clinical course of this correlation.

Nonetheless, studies have already reported an association between chemosensory alterations 
and COVID-19. They have also verified a significant increase in the incidence of these alterations at the onset of the disease. It is indicated that smell and/or taste dysfunction assessments be made in the anamnesis as an indicator of COVID-19. To conclude, the data show a probable association between smell and taste alterations and COVID-19 infection in such patients.

Author's Contribution

All authors have contributed equally to this work.

\section{REFERENCES}

1. Lechien IR.Olfactory and gustatory dysfunctions as a clinical presentation of mild-to-moderate forms of the coronavirus disease (COVID-19): a multicenter European study. European Archives of Oto-Rhino-Laryngology. 2020: 1-11.

2. Speth Marlene M. Olfactory Dysfunction and Sinonasal Symptomatology in COVID-19: Prevalence, Severity, Timing, and Associated Characteristics. Otolaryngology--Head and Neck Surgery. 2020.

3. WHO: World Health Organization. Folha informativa - COVID-19 (doença causada pelo novo coronavírus) [internet]. 2020. [Acesso em: 31 maio 2020]. Disponível em: https://www.paho.org/bra/index.php?option=com_content\&view=article\&id=6101:COVID-19\&Itemid=875\#datas-noticificacoes

4. Lee Yonghyun.Prevalence and duration of acute loss of smell or taste in COVID-19 patients.Journal of Korean medical science. 2020, 35(18).

5. Hjelmeaeth J, Dagfinn S. Loss of smell or taste as the only symptom of COVID-19. Tidsskrift for Den norske legeforening. 2020.

6. Heidari F. Anosmia as a prominent symptom of COVID-19 infection. Rhinology. 2020, 58.(3): 302-303.

7. Machado CG.Anosmia and ageusia as initial or unique symptoms after sars-cov-2 virus infection. 2020.

8. Russell B. Anosmia e ageusia estão surgindo como sintomas em pacientes com COVID-19: o que as evidências atuais dizem?. Ecancer Medical Science. 2020, 14.

9. Mao L, Wang M, Chen S, et al. Neurological manifestations of hospitalized patients with COVID-19 in Wuhan, China: a retrospective case series study. MedRXiv. 2020

10. Giacomelli A, Pezzati L, Conti F, et al. Self-reported olfactory and taste disorders in patients with SARS - CoV - 2: a cross-sectional study. Clin Infect Dis. 2020

11. Vaira LA, Salzano L, Deiana G, De Riu L. Anosmia and ageusia: common findings in patients with COVID - 19. Laringoscópio.

12. Moher $D$, Shamseer $L$, Clarke $M$, et al. Preferred reporting items for systematic review and meta-analysis protocols (PRISMA-P) 2015 statement. Syst Rev. 2015;4(1):1. Published 2015 Jan 1. doi:10.1186/2046-4053-4-1.

13. Pithon MM, Sant\&\#39; Anna LI, Baião FC, dos Santos RL, Coqueiro Rda $\mathrm{S}$, Maia LC. Assessment of the effectiveness of mouthwashes in reducing cariogenic biofilm in orthodontic patients: A systematic review. J Dent. 2015;43:297-308.

14. Beltrán-Corbellini, A. Acute-onset smell and taste disorders in the context of COVID-19: a pilot multicenter PCR-based case-control study. European Journal of Neurology. 2020.

15. Vaira A. Olfactory and gustatory function impairment in COVID-19 patients: Italian objective multicenter-study. Head \& Neck. 2020.

16. Tian S, Hu N, Lou J. Characteristics of COVID-19 infection in Beijing. Infect. 2020;80:401-406.
17. Massarelli O, Vaira LA, Biglio A, Gobbi R, Dell'aversana Orabona G, De Riu $G$. Sensory recovery of myomucosal flap oral cavity reconstructions. Head Neck. 2018;40:467-474.

18. Cain WS, Gent JF, Goodspeed RB, Leonard G. Evaluation of olfactory dysfunction in the Connecticut chemosensory clinical research center. Laryngoscope. 1988;98:83-88.

19. Vaira LA, Salzano G, De Riu G. The importance of olfactory and gustatory disorders as early symptoms of coronavirus disease (COVID-19). Br J Oral Maxillofac Surg. 2020.

20. Lechien JR, Chiesa-Estomba CM, De Siati DR, et al. Olfactory and gustatory dysfunctions as a clinical presentation of mild-to-moderate forms of the coronavirus disease (COVID-19): a multicenter European study. Eur Arch Otorhinolaryngol. 2020.

21. Yan CH, Faraji F, Prajapati DP, Boone CE, DeConde AS. Association of chemosensory dysfunction and COVID-19 in patients presenting with influenza-like symptoms [published online April 12, 2020]. Int Forum Allergy Rhinol.

22. Kaye R CC, Kazahaya K, Brereton J. COVID-19 anosmia reporting tool: initial findings. Accepted preprint for Oto-HNS. 2020.

23. Pallanti S. Importance of SARs-Cov-2 anosmia: From phenomenology to neurobiology. Compr Psychiatry. 2020 May 11;100:152184. doi: 10.1016/j. comppsych.2020.152184. Epub ahead of print. PMID: 32422426; PMCID: PMC7211704

24. Sedaghat AR, Isabelle G, Marlene MS. Olfactory Dysfunction: A Highly Prevalent Symptom of COVID-19 With Public Health Significance. Otolaryngology-Head and Neck Surgery.2020.

25. Vaira LA, Salzano G, De Riu G. The importance of olfactory and gustatory disorders as early symptoms of coronavirus disease (COVID-19). Br J Oral Maxillofac Surg. 2020.

26. Vaira LA, Deiana G, Fois $A G$, et al. Objective evaluation of anosmia and ageusia in COVID-19 patients: a single-center experience on 72 cases. Head Neck. 2020.

27. Vaira LA, Salzano G, Petrocelli M, Deiana G, Salzano FA, De Riu G. Validation of a self-administered olfactory and gustatory test for the remotely evaluation of COVID-19 patients in home quarantine. Head Neck. 2020.

28. Hopkins, Claire, et al. "Early recovery following new onset anosmia during the COVID-19 pandemic-an observational cohort study." Journal of Otolaryngology-Head \& Neck Surgery.2020. 49: 1-6.

29. Lechien JR. Objective olfactory evaluation of self-reported loss of smell in a case series of 86 COVID-19 patients. Head \& Neck. 2020.

30. Veyseller B, Ozucer B, Karaaltin AB. Connecticut (CCCRC) olfactory test: normative values in 426 healthy volunteers. Indian J Otolaryngol Head Neck Surg. 2014;66:31-34.

31. Vaira LA. Anosmia e ageusia: achados comuns em pacientes com COVID - 19. O laringoscópio. 2020. 